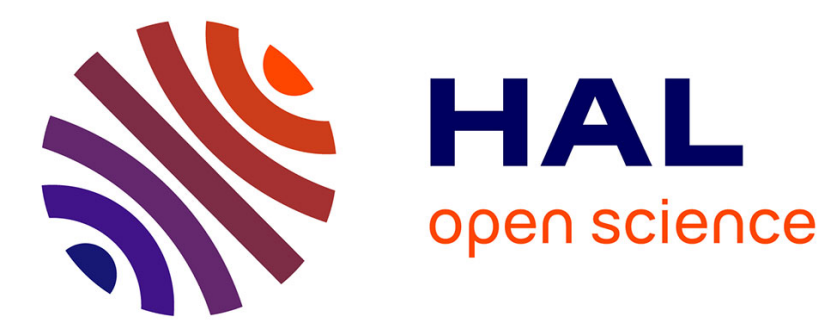

\title{
Structural reliability analysis of steel sheet-pile seawalls subjected to corrosion in harbour environment
}

\author{
Jérôme Boéro, Humberto Yáñez-Godoy, Bruno Capra, Franck Schoefs
}

\section{To cite this version:}

Jérôme Boéro, Humberto Yáñez-Godoy, Bruno Capra, Franck Schoefs. Structural reliability analysis of steel sheet-pile seawalls subjected to corrosion in harbour environment. 10th International Conference on Applications of Statistics and Probability in Civil Engineering (ICASP'11), 2011, Zurich, Switzerland. 10.1201/b11332 . hal-01008970

\section{HAL Id: hal-01008970 https://hal.science/hal-01008970}

Submitted on 16 Jun 2020

HAL is a multi-disciplinary open access archive for the deposit and dissemination of scientific research documents, whether they are published or not. The documents may come from teaching and research institutions in France or abroad, or from public or private research centers.
L'archive ouverte pluridisciplinaire HAL, est destinée au dépôt et à la diffusion de documents scientifiques de niveau recherche, publiés ou non, émanant des établissements d'enseignement et de recherche français ou étrangers, des laboratoires publics ou privés. 


\title{
Structural reliability analysis of steel sheet-pile seawalls subjected to corrosion in harbour environment
}

\author{
J. Boéro, H. Yáñez-Godoy \& B. Capra \\ OXAND S.A., Avon, France \\ F. Schoefs \\ LUNAM Université, Université de Nantes-Ecole Centrale Nantes, GeM, \\ Institute for Research in Civil and Mechanical Engineering, Nantes, France
}

\section{INTRODUCTION}

This article summarizes research carried out in the framework of the GEROM (risk management of marine and river harbor structures) project with the Scientific Interest Group MRGenCi (www. mrgenci.org). The main objective of the project is to develop a risk management methodology to assist owners in establishing decision-making procedures through maintenance master plans. The project is split into two phases: the initial phase consists of a study into maintenance management practices for harbor infrastructure and a preliminary risk analysis to identify vulnerable structures (ageing and stakes); the second phase then consists in quantifying the risks associated with the vulnerable structures identified in the initial phase.

The initial phase has been described in several papers (Boéro et al., 2009a, b). The present article is concerned only with the second phase, specifically the reliability analysis of steel sheet-pile seawalls undergoing uniform corrosion.

For this purpose, a stochastic (spatial-temporal) model of steel corrosion is proposed, based on a statistical analysis of data collected from several French ports in multiple zones that have been exposed to marine environment for varying lengths of time. At the preliminary stage, an in-depth understanding of the following issues is necessary:

- interpretation of the experimental data and physico-chemical phenomena which allow spatial corrosion to be treated essentially as a onedimensional problem, according to the depth of the structures under consideration (Boéro et al., 2009c). An analysis of corrosion mechanisms shows that the process can be modeled by 5 independent random variables corresponding to 5 different exposure zones, each one based on a different random context;

- probabilistic modeling for taking into account the variability of the phenomena. Having taken the preceding points into consideration, the stochastic time-dependent corrosion model presented in this paper is based on the temporal evolution of the probability distribution parameters defining steel loss of thickness in each exposure zone.

Predictions resulting from the corrosion model are then used to perform a time-function reliability calculation for corroded harbor structures. A coupled approach between a FORM-algorithm and deterministic finite element model (Cast3M) is used to assess the $\beta$ index. An analysis of the effect of the basic variables with time concludes the paper.

\section{MODELLING OF STOCHASTIC CORROSION FIELDS IN STEEL HARBOUR STRUCTURES BASED ON FEEDBACK FROM FRENCH PORTS}

The proposed corrosion model takes into account the spatio-temporal aspects of corrosion on steel sheet piles seawalls or cofferdams. It is based, after data cleansing, on a statistical analysis of over 35000 measurements taken from several French ports (Boéro et al., 2009c).

The model is based on the general hypothesis that corrosion can be considered to be a decoupled phenomenon on the $R^{2}$ plane of a structure; that is, in the length direction $x$ and along the depth $z$.

The spatial aspect of corrosion in the $\mathrm{x}$-direction is represented by the deterministic tendency $T\left(x, z_{j}, t\right)$ which evolves in time $t$ and depends on the exposure zone $z_{j}$ (tidal zone, immersion zone, etc.). Corrosion may be considered as being uniform in the z-direction within a given exposure zone $z_{j}$ (tidal zone, immersion zone, etc.). The corrosion distribution $c\left(z_{j}, t, \theta\right)$ is therefore assumed to be independent of $x$, dependent on the time $t$ and discretized along the depth $z$ by exposure zone $z_{i}$. Thus the predictive corrosion model takes the following form (1):

$c\left(x, z_{j}, t, \theta\right)=T\left(x, z_{j}, t\right)+\mathrm{c}\left(z_{j}, t, \theta\right)$ 


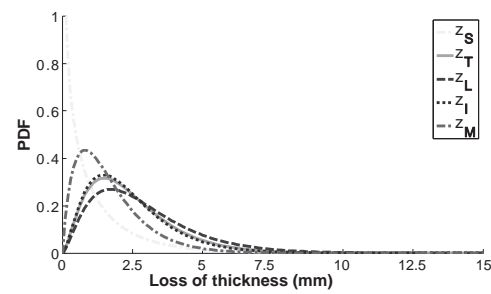

Figure 1. Steel thickness loss distributions obtained from the corrosion model for the different zones over a time period $\mathrm{t}=25$ years.

where $c\left(x, z_{j}, t, \theta\right)$ : loss of thickness as a function of the $\mathrm{x}$-coordinate and the time $t$, for the exposure zone $z_{j}(\mathrm{~mm}) ; T\left(x, z_{j}, t\right)$ : deterministic tendency with respect to a constant mean corrosion level throughout the $\mathrm{x}$-direction; $c\left(z_{i}, t, \theta\right)$ : random variable representing the loss of thickness with time $t$ for the exposure zone $z_{j}(\mathrm{~mm})$.

The Gamma probability distribution is used to characterize the variability of the corrosion $c\left(z_{j}, t, \theta\right)$, since it is the theoretical probability law that can be best fitted, in terms of maximum likelihood, to the empirical distribution of steel loss of thickness. The Gamma distribution is characterized by a shape parameter $\alpha$ and a scale parameter $\beta$ which depends on the mean and standard deviation of steel loss of thickness and which evolves, according to the present model and in the absence of other information on the stochastic structure, in a spatiotemporal manner. Steel thickness loss distributions obtained from the corrosion model for a 25 year exposure period in the marine environment are shown in Figure $1\left(\mathrm{z}_{\mathrm{S}}=\right.$ Splash; $\mathrm{z}_{\mathrm{T}}=$ Tidal; $\mathrm{z}_{\mathrm{L}}=$ Low seawater level; $\mathrm{z}_{\mathrm{I}}=$ Immersion; $\mathrm{z}_{\mathrm{M}}=$ Mud).

The paper presents the complete model, including the piece-wise stationary stochastic field with depth.

\section{TIME-DEPENDENT STRUCTURAL RELIABILITY OF A CORRODED STEEL SHEET PILES SEAWALL}

Based on the previous corrosion model, a time dependent reliability analysis is carried out on a sheet-pile wall (Figure 2). For simplicity and in view to simplify the analysis of results we consider in this paper that $U$ piles are uniformly corroded with the "out-pans" kinetics. Moreover, if the corrosion has been shown to be stationary, the identification correlation length along $x$ is still a challenge (Boéro 2010): we assume here that the correlation is negligible after 20 meters and that the wall can be modeled with a 2D model (Figure 2). Thus we consider the stability of a sheet pile 2 meter wide, the distance between tie-rods. Finally, the tie-rods

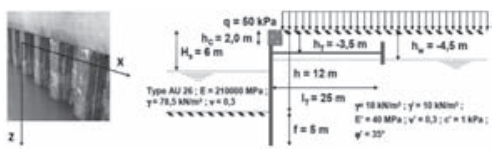

Figure 2. Geometrical and mechanical characteristics of the quay.

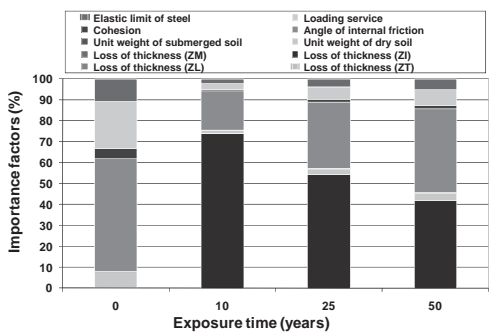

Figure 3. Evolution of importance factors with time (point of the section towards the seaside excavation).

are protected (galvanization) and are considered not to be affected by corrosion.

Let us focus only on sensitivity factors. Figure 3 reports the values of these factors obtained when computing the reliability index in the most critical section at time $\mathrm{t}=0,10,25$ and 50 years. The results are very interesting. At the beginning of the lifetime, dominant random variables are angle of internal friction, loading service (operating excess load) and steel yield stress with a pro-eminent role of the first $(55 \%)$. After 10 years, the role of the corrosion in zone $\mathrm{Z}_{\mathrm{I}}$ is already pro-eminent (more than 70) and angle of internal friction follows. This role of corrosion decreases with time and is the same than the role of angle of internal friction after 50 years (almost $40 \%$ ). Note that of course this trend depends on the position of the steel section under consideration. If we focus on the section near the tie-rod (see figure 9), the role of corrosion random variable, here in area $Z_{\mathrm{T}}$ increases with time.

\section{REFERENCES}

Boéro, J., Schoefs, F., Capra, B. \& Rouxel, N. 2009a. Technical management of French harbour structures. Part 1: Description of built assets. PARALIA, Published on line December 21th 2009, 2: 6.1-6.11.

Boéro, J., Schoefs, F., Capra, B. \& Rouxel, N. 2009b. Technical management of French harbour structures. Part 2: Current practices, needs - Experience feedback of owners. PARALIA, Published on line December 21th 2009, 2: 6.13-6.24.

Boéro, J., Schoefs, F., Melchers, R. \& Capra, B. 2009c. Statistical Analysis of Corrosion Process along French Coast. In. Furuta, Frangopol \& Shinozuka (eds), ICOSSAR'09; Proc. int. conf., Osaka, Japan, 13-19 September 2009. London: Taylor \& Francis Group. 